\title{
Spatial Model of Deforestation in Kalimantan from 2000 to 2013
}

\author{
Judin Purwanto $^{1,2^{*}}$, Teddy Rusolono ${ }^{3}$, Lilik Budi Prasetyo ${ }^{4}$ \\ ${ }^{1}$ Graduate School of Bogor Agricultural University, Dramaga Main Road, Campus IPB Dramaga, Bogor, Indonesia 16680 \\ ${ }^{2}$ The Ministry of Environment and Forestry of Indonesia, Jakarta, Indonesia 10270 \\ ${ }^{3}$ Department of Forest Management, Faculty of Forestry, Bogor Agricultural University, Academic Ring Road, Campus IPB \\ PO Box 168 Bogor, Indonesia 16680 \\ ${ }^{4}$ Department of Forest Resource Conservation and Ecotourism, Faculty of Forestry, Bogor Agricultural University, Academic \\ Ring Road, Campus IPB Dramaga, Bogor, Indonesia 16680
}

Received June 26, 2015/Accepted August 31, 2015

\begin{abstract}
Forestry sector is the biggest carbon emission contributor in Indonesia which is mainly caused by deforestation. A significant area of forest cover still can be found in Kalimantan Island (one of the largest island in Indonesia) although an alarming rates deforestation is also exist. This study was purposed to established spatial model of deforestation in Kalimantan islands. This information is expected to provide options to develop sustainable forest management in Kalimantan trought optimizing environment and socio-economic purposes. This study used timeseries land cover data from the Ministry of Environment and Forestry (2000-2013) and is validated by SPOT 5/6 images in 2013. The spatial model of deforestation were developed using binary logistic. The results of logistic regression analysis obtained spatial model of deforestation in Kalimantan $=1.1480714-(0.033262 *$ slope $)-$ $(0.002242 *$ elevation $)-(0.000413 *$ distance from forest edge $)+\left(0.000045^{*}\right.$ Gross Regional Domestic Product $)$. Validation test showed overall accuracy about $79.64 \%$ and $77.01 \%$ for models of deforestation in 2000-2006 and 2006-2013 respectively.
\end{abstract}

Keywords: spatial model, logistic regression, deforestation, Kalimantan

*Correspondence author, email: judinpurwanto@gmail.com,ph.: +62-81319541442

\section{Introduction}

Forestry sector is the biggest carbon emission contributor in Indonesia (Boer et al. 2010). Yet, forest absorbs carbon emissions by photosynthesis processes and stores it in the forest biomass. These are the main factors why forestry plays an important role tomitigate climate change.

Emission in forestry sector is mainly caused by deforestation for various purposes. The Ministry of Forestry (2014) stated that Indonesia's forest cover in Indonesia in 2013 was around 96.49 million ha out of its 187.92 million ha total land area. Furthermore, the data from the shows that the deforestation rate in Indonesia during 2012-2013 about 0.96 million ha year ${ }^{-1}$, while the reforestation rate about 0.27 million ha year ${ }^{-1}$. Data from other states that deforestation Indonesia in the period 2000-2012 an average of around 0.84 million ha year ${ }^{-1}$ and the reforestation of about 0.48 million ha year ${ }^{-1}$ (Margono 2014).

The Kalimantan islands is part of Indonesia where the forest coverage is large with the high deforestation rate (IPSDH 2014). Kalimantan has experienced heavy deforestation and forest degradation during the past 2 decades (Langler et al. 2007). Generally, the trigger of deforestation is biophysical and socio-economic. Biophysical drives in example are the elevation and slope (Prasetyo et al. 2009; Kumar et al.2014). Socio-economic driver in example are the demographic and income rate (Romijn et al. 2013). Deforestation in Kalimantan are caused by elevation and high demand of the farming or plantation area, in which also occurred in protected areas (Scriven et al. 2015). Burn et al. (2015) stated that economic force will impose strong pressure on Kalimantan forests. This condition requires good management to preserve the forests of Kalimantan and to avoid damage to forests such as Java (Prasetyo et al. 2009) and Sumatra (Margono et al. 2012) where forest cover approximately $30 \%$ of the total land area.

Spatial model can be used as a tool to find the factors that significantly contribute to deforestation. Mas et al. (2004) described that deforestation model potentially gave more benefits that consist of: providing a better understanding of how driving factors govern deforestation, generating scenario of deforestation rate in the future, predicting location of deforestation and supporting the design of policy responses to deforestation. Spatial model of deforestation is expected to provide a more detail information on 
deforestation drivers in Kalimantan in order to develop plans of sustainable forest management with optimal environment and socio-economics functions. The spatial model of deforestation can be constructed with a variety of techniques or methods. Logistic regression approach is proven to be able to be used in analyzing deforestation (Arkehi 2013).

Park (2013) compared the development of critical model by using frequency ratio (FR), analytic hierarchy process (AHP), logistic regression (LR), and artificial neural network (ANN). Those 4 methods give values of accuracy which are not too differently and logistic regression is considered as the most optimal method. Logistic regression can be used to develop suitability/susceptibility model since it can process huge data, does not require questionnaire survey, does not require much time, and can be easily understood. Burn et al. (2015) developed models of deforestation of protected area in Indonesia use methods autologistic and von Thunen spatial-autoregressive models. Validation results indicated that both models had less different. The choice of the model will depend on data availability and purpose. The von Thunen model can be useful if the spatial data are scarce or available only at a single time of point. The autologistic model can provide higher accuracy, when the aim is to obtain more spatially accurate predictions than a mechanistic understanding of drivers of deforestation.
Linkie et al. (2004) developed spatial model of deforestation in the low land of Sumatra during 1985, 1992, and 1999 by using logistic regression. This study showed that slope, distance from the logging track, and distance from the road were found to be the important variables in model of deforestation. Prasetyo et al. (2009) developed deforestation model during 2000, 2005, and 2008 by using logistic regression in Java, the important drivers were population density, road density, and percentage of population having agricultural sector as source of income.

The objective of this study is to develop spatial model to identify which drivers and to predict the location of deforestation in Kalimantan. This information is expected to provide options to develop sustainable forest management plan in Kalimantan through optimizing environment and socio-economic purposes.

\section{Methods}

Summary steps of the study is shown in Figure 1. The main data of this study is the landcover map of 2000 to 2013 from the Ministry of Environment and Forestry of Indonesia (MoEF). The supporting data were the forestry thematic base map (peta dasar tematik kehutanan, so-called PDTK) of 2006, the peat land map from the Ministry of Agriculture (MoA), SPOT 5/6 satellite image of 2013, Shuttle Radar Topography Mission (SRTM) $30 \mathrm{~m}$ spatial resolution, the

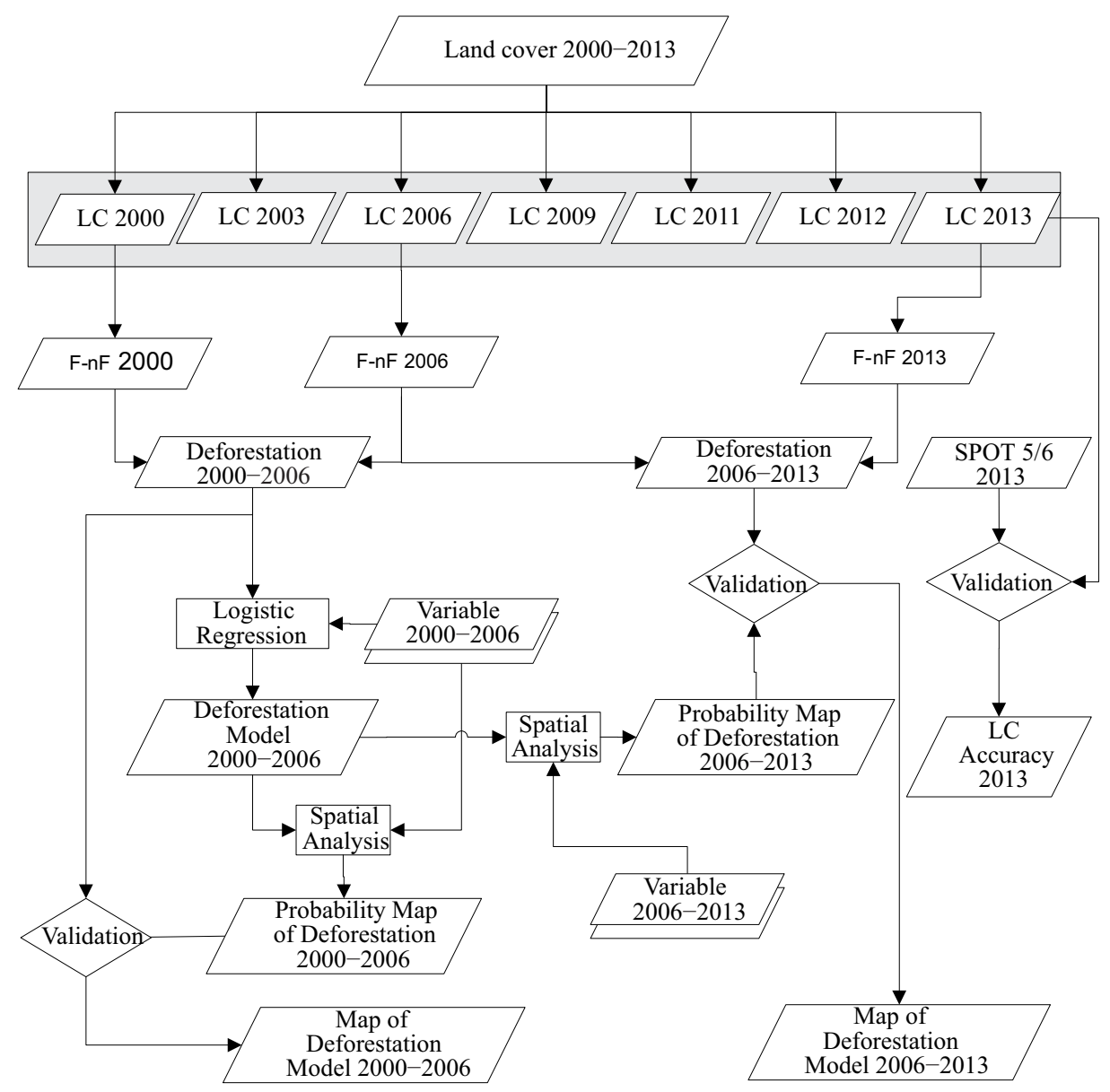

Figure 1 Flow chart of metods. Land cover (LC), natural forest $(\mathrm{F})$, non natural forest $(\mathrm{nF})$. 
Village Potential Map (peta potensi desa, so-called PODES), and gross regional domestic product (GRDP) of 2003 and 2008 from Indonesian Statistic Bureau (Badan Pusat Statistik, so-called BPS). The software used to analyze the data were ArcGIS, Microsoft Excel, and SPSS.

Validation of landcover map Validation was conducted by comparing MoEF's landcover map 2013 and the available high resolution image SPOT 5/6 of 2013. According to Doris and Cardille (2011), high resolution image can be used as a reference to validate medium or low resolution image. Validation of locations were systematically arranged according to the national forest inventory (NFI) plots (DirjenPlan 2014). Those combinations resulted in 307 checking points (Figure 2). Validation method using higher resolution image can save up time and cost. The next procedure was the accuracy assesment. The widely used accuracy calculation, i.e error matrix (overall accuracy, producer accuracy and user accuracy) was used in this study (Foody 2002).

Developing deforestation spatial model Deforestation spatial model was developed by using logistic regression based on the data of 2000-2006 and then the generated model was applied for forcasting the 2006-2013 period and was validated by using actual land cover data within 2006-2013. Deforestation was identified by analyzing natural forest conversion into non-natural forest. This data of deforestation was later used as dependent variable.

The drivers of deforestation Several spatial explanatory variables (Table 2) describing potential proximate causes of deforestation are generated as follow:

1 Slope and elevation were constructed from SRTM $30 \mathrm{~m}$ resolution with raster surface analysis.

2 Peatland were constructed from the MoA's peatland data

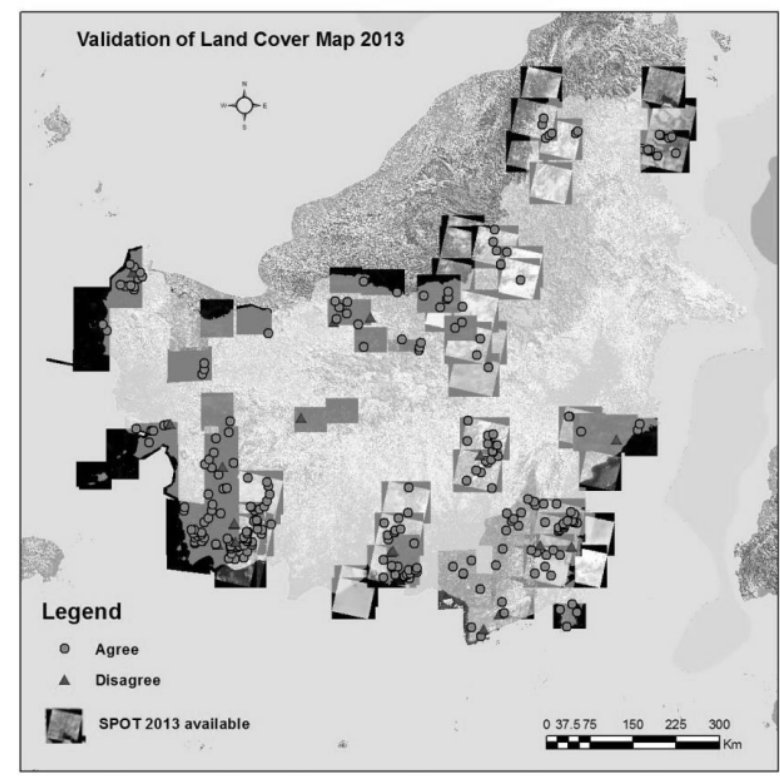

Figure 2 Cheking point validation of MoEF land cover map 2013 year.

Table 1 Data used and iteration technique

\begin{tabular}{|c|c|c|c|c|}
\hline Variable & Unit & Scale & Source & Iteration technique \\
\hline Slope $\left(\mathrm{X}_{1}\right)$ & $\%$ & Ratio & SRTM & Spatial analysis (raster surface/slope) \\
\hline Elevation $\left(\mathrm{X}_{2}\right)$ & $\mathrm{m}$ asl & Ratio & SRTM & Spatial analysis \\
\hline Peat land $\left(\mathrm{X}_{3}\right)$ & & Nominal & Peat land map, MoA & Spatial analysis \\
\hline Distance from forest edge $\left(\mathrm{X}_{4}\right)$ & meter & Ratio & Land cover map, MoEF & Spatial analysis (euclidean distance) \\
\hline Distance from estate crop edge $\left(\mathrm{X}_{5}\right)$ & meter & Ratio & Land cover map, MoEF & Spatial analysis (euclidean distance) \\
\hline Distance from road $\left(\mathrm{X}_{6}\right)$ & meter & Ratio & PDTK MoEF & Spatial analysis (euclidean distance) \\
\hline Distance from river $\left(\mathrm{X}_{7}\right)$ & meter & Ratio & PDTK MoEF & Spatial analysis (euclidean distance) \\
\hline Population $\left(\mathrm{X}_{8}\right)$ & persons & Ratio & PODES, BPS & $\begin{array}{l}\text { Spatial analysis (interpolation from the village } \\
\text { center) }\end{array}$ \\
\hline Farmer households $\left(\mathrm{X}_{9}\right)$ & $\begin{array}{l}\text { households per } \\
\text { village }\end{array}$ & Ratio & PODES, BPS & $\begin{array}{l}\text { Spatial analysis (interpolation from the village } \\
\text { center) }\end{array}$ \\
\hline $\operatorname{GDRB}\left(\mathrm{X}_{10}\right)$ & $\begin{array}{c}\text { millions IDR } \\
\text { per sub-province }\end{array}$ & Ratio & BPS & $\begin{array}{l}\text { Spatial analysis (interpolation from the village } \\
\text { center) }\end{array}$ \\
\hline
\end{tabular}


Table 2 The test results multicollinearity between independent variables

\begin{tabular}{lrr}
\hline \multicolumn{1}{c}{ Model } & \multicolumn{2}{c}{ Collinearity Statistics } \\
\cline { 2 - 3 } & Tolerance & VIF \\
Slope & 0.539 & 1.856 \\
Elevation & 0.297 & 3.367 \\
Peatland & 0.876 & 1.142 \\
Distance from forest edge 2000 & 0.577 & 1.733 \\
Distance from estate crop edge 2000 & 0.392 & 2.552 \\
Distance from road & 0.545 & 1.834 \\
Distance from river & 0.931 & 1.074 \\
Population 2003 & 0.275 & 3.641 \\
Farmer house holds 2003 & 0.262 & 3.820 \\
GRDB 2003 & 0.909 & 1.100 \\
\hline
\end{tabular}

Dependent Variable: deforestation

by conversion to $30 \mathrm{~m}$ raster resolution. The results was categorical data peatland and non peatland.

3 Distance from forest edge (DFE) was calculated using euclidean distance equation, where forest edge were extracted from initial land cover.

4 Distance from estate crop edge (DCE) was calculated using euclidean distance equation, where estate crop edges were extracted from initial land cover.

5 Distance from road (DRo) was calculated using euclidean distance equation, where road data was derived from PDTK.

6 Distance from river (DRi) wascalculated using euclidean distance equation, where river data was derived from PDTK.

7 Human population and the number of farmer households was constructed from from PODES data. Both data was interpolated from village center point using natural neigbor technique.

8 Gross Regional Domestic Product (GDRB) map was constructed from sub-province area and sub-province GDRP data at 2000 constant price from BPS.

All variables were standardized into $30 \mathrm{~m}$ raster resolution and world mercator coordinate system.

Sampling procedure Minimum number of samples was determined by using slovin Equation (Tejada \& Punzalan 2012) as shown in Equation [1].

$n=\frac{N}{1+N \alpha^{2}}$

note:

$\mathrm{n}=$ number of sample

$\mathrm{N}=$ number of population

$\alpha=$ significance level

Sample determination method used was stratified random sampling (Huang 2006). Stratum is subset of population which generally its characteristics are classification. Sample was taken from each category of deforested land (1) and nondeforested land $(0)$ by considering the distribution at the study area. A sampling design common to logistic regression usually refers to the same area in each stratum to eliminate spatial autocorrelation (Rutherford et al. 2007). Based on the calculation, 400 points as a number of minimum sample was obtained with $\mathrm{N}=323,271,656$ pixel (forested area in 2000) and significance level 5\%. The number of samples used for logistic regression analysis was 800 points. The number representing 2 categories of land with equal number in each category: 400 points of deforested land and 400 points for non deforested land or stable forest (Figure 3).

Logistic regression Logistic regression is a multiple linear regression with its dependent variable dummy expressions i.e. 1 and 0. Logistic regression equation (Menard 2002) is shown in Equation [2].

$$
\operatorname{Logit}\left(P_{i}\right)=\alpha+\beta_{1} X_{1}+\beta_{2} X_{2}
$$

note:

$P_{i}=$ probability of deforestation

$X_{\mathrm{n}}=\mathrm{n}^{\text {th }}$ predictor variable

$\beta_{\mathrm{n}}=$ coefficient of variable $X_{\mathrm{n}}$

$\alpha=$ regression constanta

$\exp =$ exponential

Methods for selecting variable used backward methods.

There are classic assumption test in multiple linear regression among others are normality test, heteroscedasticity test, autocorrelated test, and multicoliniarity test. Out of those 4 tests, the normality test, heteroscedasticity test, and autocorrelated test corresponds with its residual value, while multicolinearity test corresponds with independent variable. For this reason, the 3 tests which related to the residual value are not necessarily conducted except multicolinearity test. Multicolinearity test is still required, because only independent variable is involved.

Variance inflation factor (VIF) is one of the methods to detect any multicolinearity. VIF is formulated as shown in Equation [3].

$(V I F)_{n}=\frac{1}{1-R_{n}^{2}}$

note :

$(V I F)_{n}=$ VIF of independent variable $X_{\mathrm{n}}$ 
$\mathrm{R}^{2}=$ determination coefficient and independent variable $X_{\mathrm{n}}$.

According to Menard (2002) when VIF value is bigger than 10 indicates that there is a problem in the multicolinearity. Treshhold VIF widely used in study is 10 (O'berin 2007). When variable is indicated having multicolinearity then it has to be eliminated. When there is no problem with multicolinearity in the variable, then it can be proceed to logistic regression analysis.

Calibration of the model The feasibility of the logistic regression model was showed by result of the value $-2 \mathrm{Log}$ Likelihood and Hosmer and Lemeshow test. A model is considered as feasible when there is reduced value of $-2 \log$ Likelihood and the significance value of Hosmer and Lemeshow test bigger than 0.05 (Hosmer and Lemeshow 2004). Discriminative test was conducted to obtain information of how valid the model to differentiate the probability of deforestation. Discriminative test was performed by calculating the reciever operating characteristic (ROC) value (Dahlan 2012).

Spatial model of deforestation The developed model of deforestation of 2000-2006 later was integrated into the chosen variable map to generate a deforestation probability map of 2000-2006. The generated probability map was later classified into a changing category and unchanging category by using cut value. Cut value was chosen based on the value of the highest kappa accuracy of the generated probability map (Fielding \& Bell 1997). Then the deforestation model of 2000-2006 using the best selection cut value was use to generated deforestation prediction map of 2006-2013 by adjusting the variables. The deforestation prediction map 2006-2013 later was validated with deforestation actual data of 2006-2013 from MoEF in order to obtain overall accuracy, producer accuracy and user accuracy values.

\section{Results and Discussion}

Land cover data accuracy Land cover validation of $\mathrm{MoEF}$ data of 2013 using available SPOT 5/6 image of 2013 (Figure 2) resulted $96.09 \%, 95.00 \%$ and $96.38 \%$. for forest and nonforest classes of overall accuracy, producer accuracy, and user accuracy.These results were not widely different from the calculation of overall accuracy on land cover data from all over Indonesia (wall to wall) in 2011 that resulted the accuracy 98\% for forest and nonforest (IPSDH 2012). Margono (2014) also calculated the overall accuracy for land cover wall to wall in 2000 for forest and non-forest classes and resulted $90.2 \%$ of accuracy. Hoekman et al. (2009) developed Kalimantan forest cover maps of 2007 year using PALSAR images and validated by using MoEF land cover data of 2006. Validation result was states as a good agreement, but quantitative value was not presented.

Binary regression logistic Test result VIF showed that there was no variable with multicolinearity since the tolerance value generated is $>0.1$ and VIF value $<10$ (Table 2). Based on the results of logistic regression analysis (Table 3), deforestation model equation was generated as shown in Equatiion [4].

$$
P_{i}=\frac{\exp Z}{1-\exp Z}
$$

note:

$\mathrm{Z}=1.1480714-(0.033262 *$ slope $)-(0.002242 *$ elevation $)-$ $(0.000413 *$ distance from forest edge $)+\left(0.000045^{*}\right.$ gross regional domestic product).

The result showed that the slope and elevation gave negative effect, it means that when the slope and is going steeper the occurence of deforestation is getting lower. Kumar et al. (2014) and Prasetyo et al. (2009) stated that slopes and elevation are the factors that influence deforestation, when the slopes is going steeper the occurrence of deforestation is getting lower. The steep of slope is usually avoided in logging activity or forest conversion because it is relatively more difficult in practice and requires higher costs (Burn et al. 2000). In Kalimantan the steep slope lies in the northern part of island.

The analysis results showed that the distance from the forest edge effect is negative, it means that the long distance of forest edge causes the deforestation occur is getting lower. Arkehi (2013) states that the distance of the forest edge are factors that influence the occurrence of deforestation, forest closer to the chances of deforestation is increasing.

The results showed that GDRP gave a positive effect, meaning that the greater GDRP the higher the incidence of deforestation. Romijn et al. (2013) and Ewers (2006) states that GDRP is a factor that affects the occurrence of deforestation, the higher the GDRP of a region, the higher the chances of deforestation. The correlation between GDRB and deforestation must be assessed with caution because they are less clear about whether deforestation later declined if countries become richer (Kaimowitz \& Angelsen 1998).

Fitting of the model The results of feasibility model test by using Hosmer and Lemeshow test showed that model was fit since it held statistical significance $0.424(>0.05)$. Nagelkerke $\mathrm{R}^{2}$ value described that $46.6 \%$ variation was explainable by model, meanwhile the rest was explained by factors other than model. The generated Nagelkerke $R^{2}$ value was only an approached value, because in logistic regression, determination coefficient can not be calculated as in linier regression. Discrimination test is conducted by calculating (ROC) (receiver operating characteristic) value. The generated ROC value from this model is $84.4 \%$. This value is considered as strong category (80-90\%) (Dahlan 2012).

Model implementation The developed model implementation by using variable map resulted in deforestation probability map 2000-2006. Later, the deforestation probability map was developed into deforestation model map 2000-2006 based on cut value 0.81 (Figure $4 \mathrm{a}$ and Table 4$)$. Thus, for probability value $(0 \leq \mathrm{P}<$ $0.81)$ was non-deforested areas, while probability value $(0.81$ $\leq \mathrm{P} \leq 1)$ was deforested areas. Deforestation model map 2006-2013 was generated from deforestation model with cut value 0.81 which was developed by adjusting variable within period 2006-2013 (distance from forest edge and GRDB) (Figure 4b). In generally of logistic regression, cut value used 
Table 3 Result of logistic regression

\begin{tabular}{|c|c|c|c|c|c|c|c|}
\hline \multicolumn{2}{|c|}{ Variables in the equation } & $\mathrm{B}^{\mathrm{a})}$ & \multirow{2}{*}{$\begin{array}{r}\text { S.E. } \\
.010\end{array}$} & \multirow{2}{*}{$\frac{\text { Wald }^{\text {c) }}}{13.521}$} & \multirow{2}{*}{$\frac{d f^{\left({ }^{1}\right)}}{1}$} & \multirow{2}{*}{$\begin{array}{r}\text { Sig.e) } \\
.000\end{array}$} & \multirow{2}{*}{$\begin{array}{r}\operatorname{Exp}(B)^{\mathrm{f}} \\
.964\end{array}$} \\
\hline \multirow{11}{*}{ Step $1^{\mathrm{a}}$} & $\mathrm{X} 1$ & -.036146 & & & & & \\
\hline & $\mathrm{X} 2$ & -.001736 & .001 & 3.818 & 1 & .051 & .998 \\
\hline & $\mathrm{X} 3$ & -.317063 & .257 & 1.523 & 1 & .217 & .728 \\
\hline & $\mathrm{X} 4$ & -.000395 & .000 & 47.442 & 1 & .000 & 1.000 \\
\hline & $\mathrm{X} 5$ & -.000002 & .000 & .699 & 1 & .403 & 1.000 \\
\hline & $\mathrm{X} 6$ & -.000005 & .000 & .068 & 1 & .794 & 1.000 \\
\hline & $\mathrm{X} 7$ & -.000010 & .000 & .102 & 1 & .749 & 1.000 \\
\hline & $\mathrm{X} 8$ & .000018 & .000 & .028 & 1 & .866 & 1.000 \\
\hline & $\mathrm{X} 9$ & .000480 & .001 & .434 & 1 & .510 & 1.000 \\
\hline & $\mathrm{X} 10$ & .000036 & .000 & 4.747 & 1 & .029 & 1.000 \\
\hline & Constant & 1.501298 & .241 & 38.838 & 1 & .000 & 4.488 \\
\hline \multirow{10}{*}{ Step $2^{\mathrm{a}}$} & $\mathrm{X} 1$ & -.036212 & .010 & 13.588 & 1 & .000 & .964 \\
\hline & $\mathrm{X} 2$ & -.001729 & .001 & 3.794 & 1 & .051 & .998 \\
\hline & $\mathrm{X} 3$ & -.316510 & .257 & 1.518 & 1 & .218 & .729 \\
\hline & $\mathrm{X} 4$ & -.000395 & .000 & 47.551 & 1 & .000 & 1.000 \\
\hline & $\mathrm{X} 5$ & -.000003 & .000 & .727 & 1 & .394 & 1.000 \\
\hline & X6 & -.000005 & .000 & .073 & 1 & .787 & 1.000 \\
\hline & $\mathrm{X} 7$ & -.000011 & .000 & .108 & 1 & .743 & 1.000 \\
\hline & $\mathrm{X} 8$ & .000578 & .000 & 1.772 & 1 & .183 & 1.001 \\
\hline & $\mathrm{X} 10$ & .000036 & .000 & 4.746 & 1 & .029 & 1.000 \\
\hline & Constant & 1.504960 & .240 & 39.370 & 1 & .000 & 4.504 \\
\hline \multirow{9}{*}{ Step $3^{\mathrm{a}}$} & $\mathrm{X} 1$ & -.036139 & .010 & 13.576 & 1 & .000 & .965 \\
\hline & $\mathrm{X} 2$ & -.001767 & .001 & 4.080 & 1 & .043 & .998 \\
\hline & $\mathrm{X} 3$ & -.326989 & .254 & 1.657 & 1 & .198 & .721 \\
\hline & $\mathrm{X} 4$ & -.000395 & .000 & 47.530 & 1 & .000 & 1.000 \\
\hline & $\mathrm{X} 5$ & -.000003 & .000 & .897 & 1 & .344 & 1.000 \\
\hline & $\mathrm{X} 7$ & -.000010 & .000 & .103 & 1 & .748 & 1.000 \\
\hline & $\mathrm{X} 9$ & .000561 & .000 & 1.707 & 1 & .191 & 1.001 \\
\hline & $\mathrm{X} 10$ & .000036 & .000 & 4.822 & 1 & .028 & 1.000 \\
\hline & Constant & 1.502684 & .239 & 39.400 & 1 & .000 & 4.494 \\
\hline \multirow{8}{*}{ Step $4^{\mathrm{a}}$} & $\mathrm{X} 1$ & -.036164 & .010 & 13.587 & 1 & .000 & .964 \\
\hline & $\mathrm{X} 2$ & -.001776 & .001 & 4.120 & 1 & .042 & .998 \\
\hline & $\mathrm{X} 3$ & -.319593 & .253 & 1.598 & 1 & .206 & .726 \\
\hline & $\mathrm{X} 4$ & -.000398 & .000 & 50.329 & 1 & .000 & 1.000 \\
\hline & $\mathrm{X} 5$ & -.000003 & .000 & .825 & 1 & .364 & 1.000 \\
\hline & $\mathrm{X} 9$ & .000541 & .000 & 1.636 & 1 & .201 & 1.001 \\
\hline & $\mathrm{X} 10$ & .000036 & .000 & 4.744 & 1 & .029 & 1.000 \\
\hline & Constant & 1.475347 & .223 & 43.609 & 1 & .000 & 4.373 \\
\hline \multirow{7}{*}{ Step $5^{\mathrm{a}}$} & $\mathrm{X} 1$ & -.035261 & .010 & 13.098 & 1 & .000 & .965 \\
\hline & $\mathrm{X} 2$ & -.002169 & .001 & 7.900 & 1 & .005 & .998 \\
\hline & $\mathrm{X} 3$ & -.336252 & .252 & 1.778 & 1 & .182 & .714 \\
\hline & $\mathrm{X} 4$ & -.000399 & .000 & 50.608 & 1 & .000 & 1.000 \\
\hline & $\mathrm{X} 9$ & .000578 & .000 & 1.861 & 1 & .172 & 1.001 \\
\hline & $\mathrm{X} 10$ & .000037 & .000 & 5.114 & 1 & .024 & 1.000 \\
\hline & Constant & 1.397210 & .205 & 46.240 & 1 & .000 & 4.044 \\
\hline \multirow{6}{*}{ Step $6^{\mathrm{a}}$} & $\mathrm{X} 1$ & -.033303 & .010 & 12.166 & 1 & .000 & .967 \\
\hline & $\mathrm{X} 2$ & -.002067 & .001 & 7.453 & 1 & .006 & .998 \\
\hline & $\mathrm{X} 4$ & -.000403 & .000 & 51.655 & 1 & .000 & 1.000 \\
\hline & $\mathrm{X} 9$ & .000496 & .000 & 1.469 & 1 & .225 & 1.000 \\
\hline & $\mathrm{X} 10$ & .000041 & .000 & 6.255 & 1 & .012 & 1.000 \\
\hline & Constant & 1.325548 & .196 & 45.936 & 1 & .000 & 3.764 \\
\hline \multirow{5}{*}{ Step $7^{\mathrm{a}}$} & $\mathrm{X} 1$ & -.033262 & .010 & 12.169 & 1 & .000 & .967 \\
\hline & $\mathrm{X} 2$ & -.002242 & .001 & 8.845 & 1 & .003 & .998 \\
\hline & $\mathrm{X} 4$ & -.000413 & .000 & 54.630 & 1 & .000 & 1.000 \\
\hline & $\mathrm{X} 10$ & .000045 & .000 & 7.795 & 1 & .005 & 1.000 \\
\hline & Constant & 1.480714 & .151 & 96.779 & 1 & .000 & 4.396 \\
\hline
\end{tabular}

a) [estimated logit coefficient $]{ }^{\mathrm{b}}[$ Standard Error of the coeffi cient $]{ }^{\mathrm{c}}[$ Wald $=[\mathrm{B} / \mathrm{S} . \mathrm{E}] 2]{ }^{\mathrm{d}}[\mathrm{df}:$ degree of freedom $]{ }^{\mathrm{e}}[$ Sig : significance level of the coefficient] ${ }^{\mathrm{f}}$ [the odds ratio of the ind ividual coefficient] 


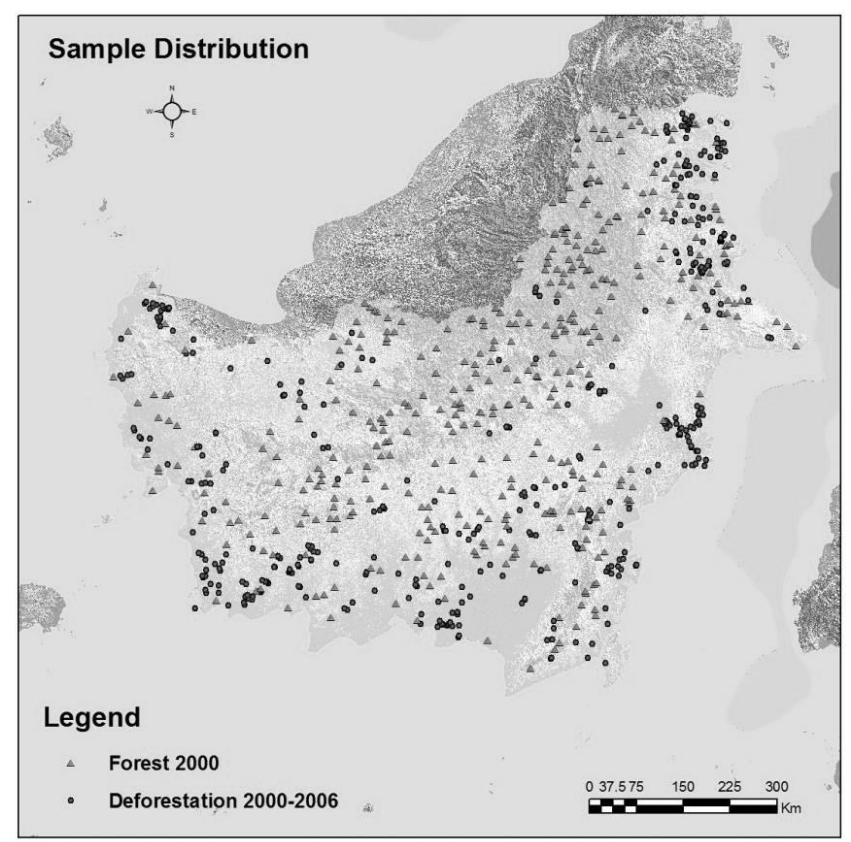

Figure 3 Distribution of samples used in the logistic regression.

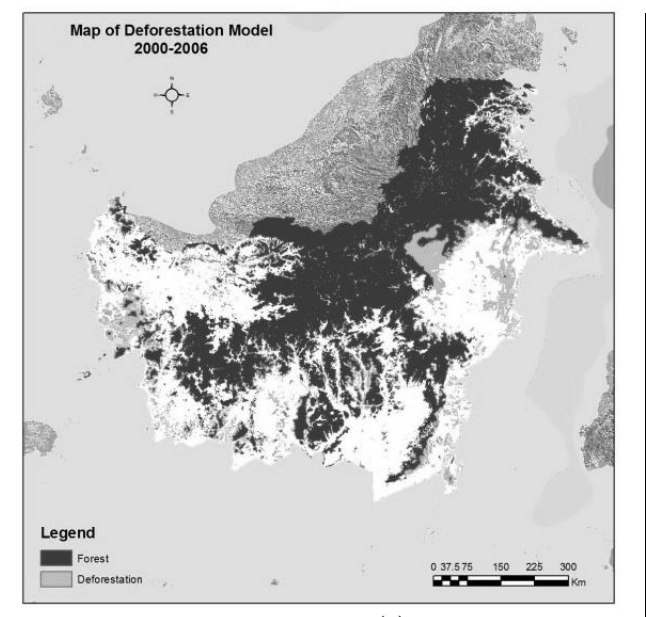

(a)

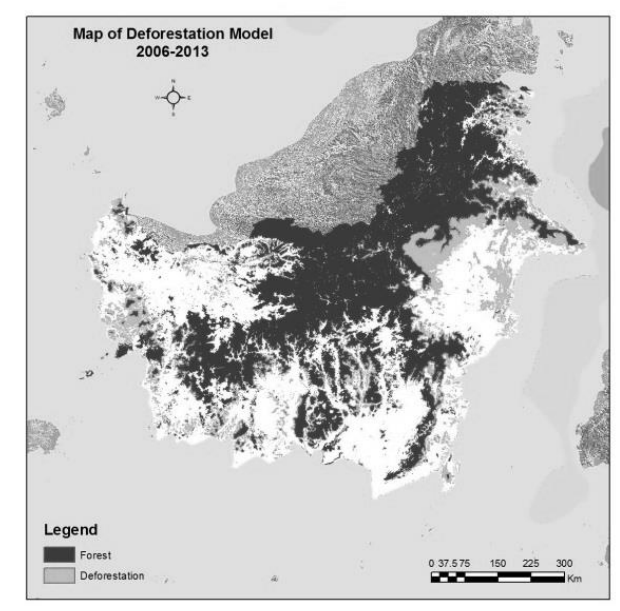

(b)

Figure 4 Map of deforestation model 2000-2006 (a) and map of deforestation model 2006-2013(b).

Table 4 Best selecting cut off of probability map of deforestation

\begin{tabular}{ccc}
\hline Cut off & Overall accuracy & Kappa accuracy \\
\hline 0.50 & 0.56228 & 0.08895 \\
0.60 & 0.61706 & 0.10409 \\
0.70 & 0.68627 & 0.12492 \\
0.80 & 0.78445 & 0.14732 \\
$\mathbf{0 . 8 1}$ a) & $\mathbf{0 . 7 9 6 4 1}$ & $\mathbf{0 . 1 4 7 8 9}$ \\
0.82 & 0.80855 & 0.14752 \\
0.83 & 0.82061 & 0.14587 \\
0.85 & 0.84286 & 0.13766 \\
90.00 & 0.88297 & 0.09595 \\
\hline a $[$ Cut off selected] & &
\end{tabular}


Table 5 The test result validation of deforestation model

\begin{tabular}{|c|c|c|c|c|}
\hline \multirow{2}{*}{$\begin{array}{c}\text { Deforestation model } \\
2006-2013\end{array}$} & \multicolumn{2}{|c|}{ Actual deforestation $2006-2013^{\text {a) }}$} & \multirow{2}{*}{ Total $^{\text {b) }}$} & \multirow{2}{*}{$\begin{array}{c}\text { Producer accuracy } \\
(\%)\end{array}$} \\
\hline & Non deforestation & Deforestation & & \\
\hline Non deforestation & $233,374,285$ & $9,659,329$ & $243,033,614$ & 96.03 \\
\hline Deforestation & $64,650,200$ & $15,587,842$ & $80,238,042$ & 19.43 \\
\hline Total & $298,024,485$ & $25,247,171$ & $323,271,656$ & \\
\hline User accuracy (\%) & 78.31 & 61.74 & & \\
\hline Overall accuracy $(\%)$ & & & 77.01 & \\
\hline
\end{tabular}

${ }^{a}\left[\right.$ Land cover MoEF ${ }^{\mathrm{a}, \mathrm{b}}[$ in pixels $]$

was 0.5 , yet to generate the best accuracy value the cut value should be adjusted. Fielding and Bell (1997) used cut value 0.62 while Soureshjani and Kimiagari (2013) used cut value 0.3 .

Model validation Test result of deforestation model validation 2000-2006 attributed with overall accuracy value $79.4 \%$, producer accuracy $13.3 \%$ and user accuracy $57 \%$. Later, this deforestation model was applied for data and independent variable of deforestation 2006-2013. Deforestation model validation test resulted in overall accuracy $77.01 \%$, producer accuracy $19.43 \%$, and user accuracy $61.74 \%$ (Table 5).

This result considered satisfactory, because the complexity of landuse change (deforestation) make it difficult to make model with an accuracy more than $85 \%$ (Huang 2006). Other spatial model which used logistic regression at different location with different variable resulted in overall accuracy $65.51 \%$, an unchanged user accuracy $65.55 \%$ and a changed user accuracy $61.10 \%$ (Park et al. 2013). Huang (2006) result unchanged overall accuracy $71 \%$ and changed user accuracy $73 \%$. Prasetyo et al. (2009) result overall accuracy $88.70 \%$, producer accuracy, and user accuracy at non-deforested areas $95.76 \%$ and $92.44 \%$. While the producer accuracy and user accuracy for deforested areas $2.97 \%$ and $13.64 \%$.

\section{Conclusion}

This study developed the spatial model of deforestation in Kalimantan using GIS and logistic regression. Test result of deforestation model validation 2000-2006 gave overall accuracy value about $79.64 \%$, meanwhile deforestation model 2006-2013 have an overall accuracy value about $77.01 \%$. Based on the result, factors that impact the deforestation in Kalimantan consist of: slope, elevation, forest edge and GDRB. Hopefully, this result will help sustainable forest management planning in Kalimantan with optimized goals in environment and socio-economic.

\section{Acknowledgement}

The authors would like to thank the Ministry of Environment and Forestry of Indonesia for sharing data.

\section{References}

Arkehi S. 2013. Modeling spatial pattern of deforestation using GIS and logistic regression: A case study of northern Ilam forests, Ilam province, Iran. Africa Journal of Biotechnology 10(72):16236-16249. http://dx.doi. org/10.5897/ AJB11.1122.

Boer R, Sulistyowati L, Zed F, Masripatin N, Kartakusuma DA, Hilman D, Mulyanto HS. 2010. Indonesia Second National Communication Under The United Nations Framework Convention on Climate Change. Jakarta: Ministry of Environment Republic of Indonesia.

Brun C, Cook AR, Lee JSH, Wich SA, Koh LP, Luis R. Carrasco LR. 2015. A comparison of Bayesian spatial models. Global Environmental Change 31:285-295. http://dx.doi.org/10.1016/j.gloenvcha.2015.02.004.

Dahlan MS. 2012. Analisis Multivariat Regresi Logistik. Jakarta: Epideminologi Indonesia.

[DirjenPlan] Direktorat Jenderal Planologi Kehutanan. 2014. Potensi Sumber Daya Hutan dari Plot Inventarisasi Hutan Nasional. Jakarta: Kementerian Lingkungan Hidup dan Kehutanan.

Dorais A, Cardille J. 2011. Strategies for incorporating highresolution google earth databases to guide and validate classifications: Understanding deforestation in Borneo. Remote Sensing 3(6):1157-1176. http://dx.doi.org/ $10.3390 / \mathrm{rs} 3061157$.

Ewers RM. 2006. Interaction effects between economic development and forest cover determine deforestation rates. Global Environmental Change 16(2):161-169. http://dx.doi.org/10.1016/j.gloenvcha.2005.12.001.

Fielding HBF, Bell JF. 1997. A review of methods for the assessment of prediction errors in conservation presence/absence models. Environmental conservation 24.01:38-49. http://dx.doi.org/10.1017/s0376892997 000088 .

Foody GM. 2002. Status of landcover classification accuracy assessment. Remote Sensing of Environment. 80(1):185-201. http://dx.doi.org/10.1016/S00344257(01)00295-4.

Hoekman D, Quiñones M, Verhoeven, R, Vissers M, Schut V, Wielaard N. 2009. PALSAR Tropical Forest Cover Mapping, Mosaicing and Validation, Case Study Borneo. In Proceedings of '4th Int. Workshop on Science and Applications of SAR Polarimetry and Polarimetric Interferometry-PolInSAR; April, 2009. Pp. 26-30. 
Hosmer JDW, Lemeshow S. 2004. Applied logistic regression. Second Edition. Canada: John Wiley \& Sons.

Huang QH, Cai YL, Peng J. 2007. Modeling the spatial pattern of farmland using GIS and multiple logistic regression: A case study of Maotiao River Basin, Guizhou Province, China. Environmental Modeling \& Assessment 12(1):55-61. http://dx.doi.org/0.1007/ s10666-006-9052-8.

[IPSDH] Direktorat Inventarisasi dan Pemantauan Sumber Daya Hutan. 2012. Rekalkulasi Penutupan Lahan 2011. Jakarta: Dirjen Planologi Kehutanan, Kementerian Kehutanan.

[IPSDH] Direktorat Inventarisasi dan Pemantauan Sumber Daya Hutan. 2014. Rekalkulasi Penutupan Lahan Indonesia Tahun 2013. Jakarta: Dirjen Planologi Kehutanan, Kementerian Kehutanan.

[IPSDH] Direktorat Inventarisasi dan Pemantauan Sumber Daya Hutan. 2014b. Deforestasi Indonesia Periode 2013 2014. Jakarta: Dirjen Planologi Kehutanan, Kementerian Kehutanan.

Langner A, Miettinen J, Siegert F. 2007. Land cover change 2002-2005 in Borneo and the role of fire derived from MODIS imagery. Global Change Biology 13(11):2329-2340. http://dx.doi.org/10.1111/j.1365-24 86.2007.01442.x.

Kaimowitz D, Angelsen A. 1998. Economic Models of Tropical Deforestation: A Review. Bogor: CIFOR.

Kumar R, Nandy S, Agarwal R, Kushwaha SPS. 2014. Forest cover dynamics analysis and prediction modeling using logistic regression model. Ecological Indicators 45:444-455. http://dx.doi.org/10.1016/j.ecolind. 2014.05.003.

Margono BA, Potapov PV, Turubanova S, Stolle F, Hansen MC. 2014. Primary forest cover loss in Indonesia over 2000-2012. Nature Climate Change. http://dx.doi.org/ 10.1038/nclimate2277.

Margono BA, Turubanova S, Zhuravleva I, Potapov P, Tyukavina A, Baccini A, Hansen MC. 2012. Mapping and monitoring deforestation and forest degradation in Sumatra (Indonesia) using Landsat time series data sets from 1990 to 2010. Environmental Research Letters 7(3):034010. http://dx.doi.org/10.1088/1748-9326 $/ 7 / 3 / 034010$
Menard S. 2002. Applied Logistic Regression Analysis: Sage University Series on Quantitative Applications in the Social Sciences. Volume 106. Thousand Oaks: Sage.

O'brien RM. 2007. A caution regarding rules of thumb for variance inflation factors. Quality \& Quantity 41(5):673-690.http://dx.doi.org/10.1007/s11135-0069018-6.

Park S, Choi C, Kim B, Kim J. 2013. Landslide susceptibility mapping using frequency ratio, analytic hierarchy process, logistic regression, and artificial neural network methods at the Inje area, Korea. Environmental Earth Sciences 68(5):1443-1464. http://dx.doi.org/ $10.1007 / \mathrm{s} 12665-012-1842-5$.

Prasetyo LB, Kartodihardjo H, Adiwibowo S, Setiawan Y, Okarda B. 2009. Spatial model approach on deforestation of Java Island, Indonesia. Journal of Integrated Field Science 6:37-44. http://dx.doi.org/10.4018/978-1-46662038-4.ch113.

Romijn E, Ainembabazi JH, Wijaya A, Herold M, Angelsen A, Verchot L, Murdiyarso D. 2013. Exploring different forest definitions and their impact on developing REDD+ reference emission levels: A case study for Indonesia. Environmental Science \& Policy 33:246-259. http://dx.doi.org/10.1016/j.envsci.2013.06.002.

Rutherford GN, Guisan A, Zimmermann NE. 2007. Evaluating sampling strategies and logistic regression methods for modelling complex land cover changes. Journal of Applied Ecology 44(2):414-424. http://dx.doi.org/10.1111/j.1365-2664.2007.01281.x.

Scriven SA, Hodgson JA, McClean C J, Hill JK. 2015. Protected areas in Borneo may fail to conserve tropical forest biodiversity under climate change. Biological Conservation 184:414-423. http://dx.doi.org/10.1016/ j.biocon.2015.02.018.

Soureshjani MH, Kimiagari AM. 2013. Calculating the best cut off point using logistic regression and neural network on credit scoring problem-A case study of a commercial bank. African Journal of Business Management 7(16):1414-1421. http://dx.doi.org/10.5897/AJB M11.394.

Tejada JJ, and Punzalan JRB. 2012. On the misuse of Slovins formula. The Philippine Statistician 61(1):129-136. 